DOI: $10.14720 /$ aas.2016.107.2.12

Agrovoc descriptors: Olea europaea, olives, varieties, plant morphology, genetic markers, genetic polymorphism, genetic variation

Agris category code: F30

\title{
Assessment of morphological and molecular variation in local olive (Olea europaea L.) in the Northern part of Iran
}

\author{
Mahnaz Nezamivand CHEGINI ${ }^{1}$, Habibollah Samizadeh LAHIJI ${ }^{2}$, Mohammad Ramezani MALEKROUDI ${ }^{3}$, \\ Mohammad Mohsenzadeh GOLFAZANI ${ }^{4}$, Ramin SEIGHALANI ${ }^{5}$
}

Received April 20, 2016; accepted August 02, 2016.

Delo je prispelo 20. aprila 2016, sprejeto 02. avgusta 2016.

\section{ABSTRACT}

Iran is known as one of the origins of olive in the world with many different olive cultivars, mainly in the north. Eighty eight accessions belong to 4 main olive cultivars were investigated by 21 morphological characters and 11 ISSR markers. Analyses of morphological characters revealed the existence of high genetic variability among cultivars. Based on both morphological and ISSR cluster analyses, 88 accessions were grouped in five distinct clusters. The ISSR primers produced 77 polymorphic bands. AMOVA showed significant difference in both between and within olive cultivars. The highest and lowest coefficient of Nei's genetic distance was observed in 'Mari' and 'Shengeh' (0.105) and 'Zard' and 'Rowghani' (0.061), respectively. In both morphological and ISSR data analyses, 'Mari' showed the highest homogeneity. The olive cultivars were not clustered based on their geographical origin.

Key words: genetic diversity, ISSR, PIC, polymorphism

\section{IZVLEČEK}

OVREDNOTENJE MORFOLOŠKE IN
MOLEKULARNE VARIABILNOSTI LOKALNE
OLJKE (Olea europaea L.) V SEVERNEM DELU IRANA

Iran je prepoznan kot eden izmed svetovnih izvorov oljke $\mathrm{z}$ mnogimi sortami, predvsem $\mathrm{v}$ njegovem severnem delu. Raziskano je bilo 88 akcesij oljke, ki so pripadale 4 glavnim sortam na osnovi polimorfizma 21 morfoloških znakov in 11 ISSR molekulskih markerjev. Analiza morfoloških znakov je odkrila veliko genetsko variabilnost med sortami. Na osnovi morfoloških znakov in ISSR molekulskih markerjev se je 88 akcesij združilo v pet skupin. Z ISSR markerji so pomnožili 77 polimorfnih fragmentov. AMOVA je pokazala značilne razlike znotraj sort in med sortami. Največji vrednosti Neiovega koeficienta kot kazalnika genetske oddaljenosti sta bili ugotovljeni med sortami Mari in Shengeh (0.105) in Zard in Rowghani (0.061). Sorta Mari je pokazala največjo homogenost na osnovi analize morfoloIoških znakov in ISSR molekulskih markerjev. Sorte oljke se niso združevale na osnovi geografskega izvora.

Ključne besede: genetska raznolikost, ISSR, PIC, polimorfizem

\section{INTRODUCTION}

The olive (Olea europaea L.) is an economically important fruit crop of the Mediterranean basin (Rao et al., 2009). Archaelogical findings revealed that olive cultivation in Iran dates back 2000 years ago (Sadeghi, 1992). At present, the old commercial olive orchards are located mainly in

\footnotetext{
Graduated student of Biotechnology, Faculty of Agriculture, The University of Guilan, Iran.

2 Associate Prof, Faculty of Agriculture Science, Department of Agronomy and Plant Breeding. Iran.

3 Research assistant prof, Olive Research Station, Iran. Ramgolbband@yahoo.com

4 Lecturer, Plant Biotechnology Faculty of Agricultural Sciences Guilan University, Iran.

5 Researcher, Agricultural Biotechnology Research Institute of Iran- North Branch.
} 
the north of Iran and more than $85 \%$ of olive production belongs to these regions (Noormohammadi et al., 2007). A large number of olive accessions are growing in Iran; therefore, many workers have reported on morphological or molecular characteristics of these accessions (Samaee et al., 2003; Hosseini-Mazinani et al., 2004, Omrani-Sabbaghi et al., 2007; Sheidai et al., 2007; Noormohammadi et al., 2012; Dastkar et al., 2013). The genetic diversity could be an important resource for the development of modern olive culture towards typical olive oil and fresh products (Hegazi et al., 2012).

The ability to discriminate olive cultivars to estimate genetic variability is an important factor for a better management of genetic resources and successful breeding programs (Milotić et al., 2005). Morphological descriptors of International Olive Council (IOC, 1993) are usually applied for characterization and identification of olive cultivars. Although the morphological characters are strongly affected by environmental conditions, the age of trees, the training systems, and the phenological stage of plants, the morphological approach continues to be the initial main step for description and classification of olive germplasm
(Rotondi and Magli, 1999). Therefore, more comprehensive studies using reliable markers are needed to gain a better understanding of the level and distribution of genetic diversity in olive cultivars. In the last years, molecular markers, such as RAPD (Belaj et al., 2001; Besnard et al., 2001; Mekuria et al., 1999; Wiesman et al., 1998), AFLP (Angiolillo et al., 1999; Sanz-Cortes et al., 2003; Sensi et al., 2003; Owen et al., 2005) and SSR (Bandelj et al., 2002; Belaj et al., 2004; Cipriani et al., 2002; Diaz et al., 2006; Khadari et al., 2003; Rallo et al., 2000; Sefc et al., 2001), have been used to characterize olive germplasm. Also, ISSRs methods have been used (Hess et al., 2000; Pasqualone et al., 2001; Gemas et al., 2004; Terzopoulos et al., 2005). Little information is available on the genetic background of Iranian domestic olive genotypes (Dastkar et al., 2013). The cross-pollination between domesticated and wild varieties caused the significant proportion of genetic diversity. Sadeghi (1992) reported that some cultivars appeared by selection of superior trees and by selection of mutation in over the years. The goal of this study is characterizing main Iranian olive cultivar in two provinces of Gilan and Zanjan by the use of ISSR markers and morphological characteristics.

\section{MATERIALS AND METHODS}

\subsection{Plant material}

Eighty-eight trees belonging to the 4 endemic cultivars including 'Mari', 'Zard', 'Shengeh' and 'Rowghani' were used in the morphological and molecular study. Trees were sampled randomly from five different locations of two provinces of Gilan and Zanjan including Gilvan, Tarom, Aliabad, Manjil and Jamalabad. Observations were made on samples of 40 healthy adult leaves and fruits for each tree. Morphological characters were measured manually and recorded for all 21 characters including leaf characters ( 3 characters) and fruit characters ( 8 characters). Then, ten characters were recorded on free stone fruits. The morphological characters were coded as binary or multistate characters (Table 1).

\subsection{DNA extraction}

Total genomic DNA was extracted from fresh leaves using $\mathrm{CTAB}$ method with some modifications (Doyle and Doyle, 1990). Leaf tissue $(0.5 \mathrm{~g})$ is ground in liquid nitrogen and incubated at $65{ }^{\circ} \mathrm{C}$ for $30 \mathrm{~min}$ in $1 \mathrm{ml}$ extraction buffer (100 mM Tris-HCl, $\mathrm{pH} 8.0 ; 20 \mathrm{mM}$ EDTA, $\mathrm{pH}$ $8.0 ; 1.4 \mathrm{M} \mathrm{NaCl}, 2 \% \mathrm{CTAB}, 1 \% \mathrm{PVP})$. An equal volume of phenol/chloroform/isoamyl alcohol (25:24:1) and $2 \mu 1 \beta$-mercaptoethanol were added to the supernatant and the whole mixture was centrifuged at $12000 \mathrm{rpm}$ for $10 \mathrm{~min}$. The precipitation of the upper phase was obtained by adding 1 volume of 2-isopropanol at $-20{ }^{\circ} \mathrm{C}$ for $20 \mathrm{~min}$ and then followed by centrifugation at $13000 \mathrm{rpm}$ for $15 \mathrm{~min}$. The DNA pellet was washed with $1 \mathrm{ml} 75 \%$ ethanol. The DNA pellet was resuspended in $50 \mu \mathrm{l}$ TE $(10 \mathrm{mM}$ Tris- $\mathrm{HCl}$, pH 8.0; 0.5 M EDTA, pH 8.0).

ISSR analysis was performed using 11 primers (Table 2). PCR reactions were performed in a $25 \mu \mathrm{l}$ volume containing $1 \times$ PCR reaction buffer 
(10 mM Tris- $\mathrm{HCl} ; 50 \mathrm{mM} \mathrm{KCl)} 1.5 \mathrm{mM} \mathrm{MgCl}_{2}$; $0.2 \mathrm{mM}$ of each dNTP; $0.3 \mu \mathrm{M}$ of a single primer; $20 \mathrm{ng}$ genomic DNA and $1.0 \mathrm{U}$ Taq DNA polymerase. The amplifications were performed in Applied Biosystems thermocycler under the following conditions: $94{ }^{\circ} \mathrm{C}, 5 \mathrm{~min} ; 94{ }^{\circ} \mathrm{C}, 30 \mathrm{~s}$; specific annealing temperature (Table 2), $45 \mathrm{~s}$; $72{ }^{\circ} \mathrm{C}, 2$ min; repeat to step 2,45 times; $72{ }^{\circ} \mathrm{C}, 5$ $\min$.

\subsection{Statistical analysis}

Canonical discriminant, cluster analysis among cultivars by within group linkage analysis and correlation analysis were conducted using SPSS-V. 20. Molecular analysis of variance (AMOVA) was performed using GeneAlex 6.4 (Peakall and Smouse, 2006) to divide the total variation to between and within olive cultivars variation. Genetic distances between all pairwise combinations of the accessions were calculated using Nei's coefficients. Genetic diversity parameters including $\mathrm{Ne}$ (number of effective alleles), H (Nei's gene diversity) and I (Shannon's information index) were calculated by GeneAlex 6.4. PIC was estimated using the Excel software. ISSR polymorphism was scored for the presence (1) or absence (0) of amplified bands and was used to estimate the dissimilarity coefficients between cultivars using simple matching's coefficient method. The dissimilarity matrix was used to construct a dendrogram using the complete linkage method. These analyses were carried out using NTSYS pc ver. 2.01 (Rohlf., 1998). The agreement between dendrograms derived from morphological characters and ISSR markers, were compared using the Mantel (1967) matrix correspondence test.

Table 1: List of morphological characteristics and their codes and meaning (IOC)

\begin{tabular}{|c|c|c|}
\hline & Variable & Intensity \\
\hline 1. & Leaf width (LW) & Narrow (1) Medium (2) Broad (3) \\
\hline 2. & Leaf length (LL) & Short (1) Medium (2) Long (3) \\
\hline 3. & Leaf shape (length/width) (LS) & Elliptic (1) Elliptic-Lanceolate (2) Lanceolate (3) \\
\hline 4. & Fruit shape (position A) & Spherical (1) Ovoid (2) Elongated (3) \\
\hline 5. & Fruit mass & Low (1) Medium (2) High (3) Very high (4) \\
\hline 6. & Fruit symmetry (position A) & Symmetry(1) Slightly asymmetry (2) Asymmetry \\
\hline 7. & $\begin{array}{l}\text { Position of maximum transvers diameter (position } \\
\text { B) }\end{array}$ & $\begin{array}{l}\text { Central (2) Towards apex } \\
\text { (3) }\end{array}$ \\
\hline 8. & Fruit apex (position A) & Obtuse (2) Rounded (3) \\
\hline 9. & Nipple & Tenuous (2) Obvious (3) \\
\hline 10. & Presence of lenticels & Few (1) Many (2) \\
\hline 11. & Size of lenticels & Large (2) \\
\hline 12. & Stone shape (position A) & Spherical (1) Ovoid (2) Elliptic (3) Elongated (4) \\
\hline 13. & Stone mass & Low (1) Medium (2) High (3) Very high (4) \\
\hline 14. & Stone symmetry (position A) & $\begin{array}{c}\text { Symmetry (1) Slightly asymmetry (2) Asymmetry } \\
\text { (3) }\end{array}$ \\
\hline 15. & Stone symmetry (position B) & Slightly asymmetry (2) \\
\hline 16. & $\begin{array}{l}\text { Position of maximum transvers diameter (position } \\
\text { B) }\end{array}$ & $\begin{array}{l}\text { Central (2) Towards apex } \\
\text { (3) }\end{array}$ \\
\hline 17. & Stone apex (position A) & Rounded (3) \\
\hline 18. & Stone base (position A) & Pointed (2) Rounded (3) \\
\hline 19. & Stone surface (position B) & Scabrous (3) \\
\hline 20. & Number of grooves & Medium (2) \\
\hline 21. & Distribution of the grooves & Grouped around the surface (2) \\
\hline
\end{tabular}


Table 2: Primers used for ISSR analysis: total number bands, polymorphic bands and \% of polymorphism obtained

\begin{tabular}{|c|c|c|c|c|c|c|}
\hline & Primers & $\begin{array}{c}\text { Sequence } 5^{\prime}- \\
3^{\prime}\end{array}$ & $\begin{array}{l}\text { Annealing } \\
\text { temperature }\end{array}$ & $\begin{array}{c}\text { Total number of } \\
\text { bands }\end{array}$ & $\begin{array}{l}\text { Polymorphic } \\
\text { bands }\end{array}$ & $\%$ polymorphism \\
\hline 1 & UBC834 & $(\mathrm{AC})_{8} \mathrm{C}$ & 48.5 & 9 & 9 & 100 \\
\hline 2 & UBC807 & $(\mathrm{AG})_{8} \mathrm{~T}$ & 43 & 7 & 7 & 100 \\
\hline 3 & UBC808 & $(\mathrm{AG})_{8} \mathrm{C}$ & 45 & 10 & 10 & 100 \\
\hline 4 & UBC809 & $(\mathrm{AG})_{8} \mathrm{G}$ & 44.7 & 7 & 6 & 85.71 \\
\hline 5 & UBC810 & $(\mathrm{GA})_{8} \mathrm{~T}$ & 47.74 & 10 & 6 & 60 \\
\hline 6 & UBC822 & $(\mathrm{TC})_{8} \mathrm{~A}$ & 43.14 & 10 & 9 & 90 \\
\hline 7 & HB12 & $(\mathrm{CAC})_{3} \mathrm{GC}$ & 34.92 & 8 & 6 & 75 \\
\hline 8 & UBC815 & $(\mathrm{CT})_{8} \mathrm{G}$ & 51.33 & 6 & 3 & 50 \\
\hline 9 & UBC816 & $(\mathrm{CA})_{8} \mathrm{~T}$ & 55.37 & 7 & 7 & 100 \\
\hline 10 & UBC823 & $(\mathrm{TC})_{8} \mathrm{C}$ & 52.52 & 7 & 5 & 71.43 \\
\hline 11 & UBC825 & $(\mathrm{AC})_{8} \mathrm{~T}$ & 56.56 & 10 & 9 & 90 \\
\hline Mean & & & & 8.27 & 7 & 70.84 \\
\hline
\end{tabular}

\section{RESULTS AND DISCUSSION}

\subsection{Morphological characterization}

Correlation among morphological characteristics were worked out at phenotypic level and presented in Table 3. The significant correlation $(p<0.01)$ were found between some characteristics, such as Fruit Shape and Fruit Apex (-0.592), Fruit Shape and Stone Shape (0.872), Fruit Symmetry (p A) and Fruit Shape (0.602), Fruit Symmetry (p A) and Fruit Apex (-.572), Fruit Symmetry (p A) and Stone Shape (0.587), Fruit Symmetry (p A) and Stone Symmetry (p A) (0.540), Fruit Symmetry (p A) and Stone Base (0.515), Fruit Apex and Stone Shape (-0.598), Fruit Apex and Stone Symmetry (p A) $(-0.523)$, as well as Stone Shape and Stone Apex (-0.504).

The dendrogram obtained by within group linkage analysis grouped the 4 cultivars and 88 individuals into five clusters (Figure 1). The first cluster included the number of the individuals of 'Rowghani' and 'Shengeh'. Individuals of 'Mari' with a limited number of 'Rowghani' and 'Shengeh' were grouped into cluster 2 and 3. All of the individuals of 'Zard' with a limited number of 'Rowghani' and 'Shengeh' ( 2 and 5 respectively) were placed into cluster 4 and 5. Among cultivars, 'Zard' and 'Mari' had the highest homogeneity. 'Shengeh' and 'Rowghani' showed high affinity. It could be due to synonymy in two cultivars. Grouping of such a mixture of accessions may be the result of the presence of synonymous/mislabeled accessions (Noormohammadi et al., 2007). These olive trees grow in the areas with close vicinity; therefore, the similarities observed among them may be due to the gene flow occurring among them.

The accuracy of the groups produced was reassessed using discriminant function analysis. The total success rate of discriminant function was $89.8 \%$, which indicates that it was successful in discriminating different groups. The canonical discriminant functions are described (Table 4). The first three functions had eigenvalues that are above 2 and jointly accounted for $98 \%$ of total variance. The first two functions accounted for $82.1 \%$ of the total variance within the individuals. Standardized discriminant function coefficient could be used to identify important characters causing variation cultivars (Table 5). In the first function, high coefficient was observed for stone shape. In the second function, stone base and leaf length had high coefficient values. In the third function, presence of lenticels and fruit mass had high coefficient values. These characters that loaded high in the three functions demonstrate their relevance in discriminating between the olive cultivars. This was further reaffirmed by the extraction of standardized canonical discriminant function coefficient. 
Assessment of morphological and molecular variation in local olive (Olea europaea L.) in the Northern part of Iran

Table 3: Correlation coefficients between 21 morphological characters

\begin{tabular}{|c|c|c|c|c|c|c|c|c|c|c|c|c|c|c|c|c|c|c|c|c|c|}
\hline & 1 & 2 & 3 & 4 & 5 & 6 & 7 & 8 & 9 & 10 & 11 & 12 & 13 & 14 & 15 & 16 & 17 & 18 & 19 & 20 & 21 \\
\hline 1 & 1.00 & & & & & & & & & & & & & & & & & & & & \\
\hline 2 & $.317^{* *}$ & 1.00 & & & & & & & & & & & & & & & & & & & \\
\hline 3 & .090 & $-.283^{* *}$ & 1.00 & & & & & & & & & & & & & & & & & & \\
\hline 4 & .092 & -.036 & .056 & 1.00 & & & & & & & & & & & & & & & & & \\
\hline 5 & .060 & -.055 & .174 & -.184 & 1.00 & & & & & & & & & & & & & & & & \\
\hline 6 & $.305^{* *}$ & .072 & .071 & $.602^{* *}$ & -.112 & 1.00 & & & & & & & & & & & & & & & \\
\hline 7 & $.218^{*}$ & $.242^{*}$ & .000 & $.298^{* *}$ & -.133 & $.329^{* *}$ & 1.00 & & & & & & & & & & & & & & \\
\hline 8 & $-.253^{*}$ & -.072 & .000 & $-.592^{* *}$ & .082 & $-.572^{* *}$ & -.208 & 1.00 & & & & & & & & & & & & & \\
\hline 9 & .194 & -.117 & .113 & .188 & .007 & $.348^{* *}$ & .106 & $-.306^{* *}$ & 1.00 & & & & & & & & & & & & \\
\hline 10 & $.280^{* *}$ & .039 & .116 & .183 & $.293^{* *}$ & $.237^{*}$ & .120 & $-.234^{*}$ & $.239^{*}$ & 1.00 & & & & & & & & & & & \\
\hline 11 & $.242^{*}$ & .046 & .076 & .205 & -.093 & $.240^{*}$ & .185 & -.185 & $.277^{* *}$ & .051 & 1.00 & & & & & & & & & & \\
\hline 12 & .073 & -.081 & -.013 & $.872^{* *}$ & -.096 & $.587^{* *}$ & .186 & $-.598^{* *}$ & .109 & $.229^{*}$ & .079 & 1.00 & & & & & & & & & \\
\hline 13 & -.001 & -.083 & .000 & -.054 & $.371^{* *}$ & $-.214^{*}$ & -.038 & .081 & $-.330^{* *}$ & .043 & -.208 & .047 & 1.00 & & & & & & & & \\
\hline 14 & $.315^{* *}$ & .026 & .068 & $.392^{* *}$ & -.124 & $.540^{* *}$ & $.223^{*}$ & $-.523^{* *}$ & .092 & .194 & .031 & $.427^{* *}$ & .000 & 1.00 & & & & & & & \\
\hline 15 & .005 & -.050 & .106 & .142 & .059 & $.316^{* *}$ & .134 & -.190 & .121 & .091 & .088 & .094 & -.003 & $.332^{* *}$ & 1.00 & & & & & & \\
\hline 16 & $.282^{* *}$ & .149 & -.123 & -.170 & .137 & -.020 & .060 & -.019 & .015 & .191 & .088 & -.115 & -.041 & .041 & .104 & 1.00 & & & & & \\
\hline 17 & -.073 & .165 & -.198 & $-.455^{* *}$ & $-.312^{* *}$ & $-.325^{* *}$ & -.032 & $.430^{* *}$ & -.189 & $-.212^{*}$ & .079 & $-.504^{* *}$ & -.070 & $-.369^{* *}$ & -.061 & .041 & 1.00 & & & & \\
\hline 18 & $.365^{* *}$ & .183 & .000 & $.455^{* *}$ & $-.217^{*}$ & $.515^{* *}$ & $.243^{*}$ & $-.495^{* *}$ & .179 & .047 & $.479^{* *}$ & $.376^{* *}$ & -.127 & $.437^{* *}$ & $.355^{* *}$ & .180 & $-.271^{*}$ & 1.00 & & & \\
\hline 19 & -.065 & .069 & .000 & .108 & -.070 & .123 & .141 & $-.246^{*}$ & .009 & $.212^{*}$ & -.162 & .131 & -.002 & .158 & .072 & -.078 & -.163 & -.007 & 1.00 & & \\
\hline 20 & -.091 & -.015 & $-.264^{*}$ & .014 & .032 & -.049 & -.194 & .120 & -.059 & -.098 & $-.232^{*}$ & .102 & .058 & -.038 & -.151 & -.072 & -.052 & $-.289^{* *}$ & -.066 & 1.00 & \\
\hline 21 & .172 & .010 & .000 & -.174 & -.115 & -.123 & -.157 & .084 & .110 & -.201 & $.243^{*}$ & $-.280^{* *}$ & -.052 & -.053 & .126 & .082 & $.323^{* *}$ & .185 & -.121 & -.050 & 1.00 \\
\hline
\end{tabular}




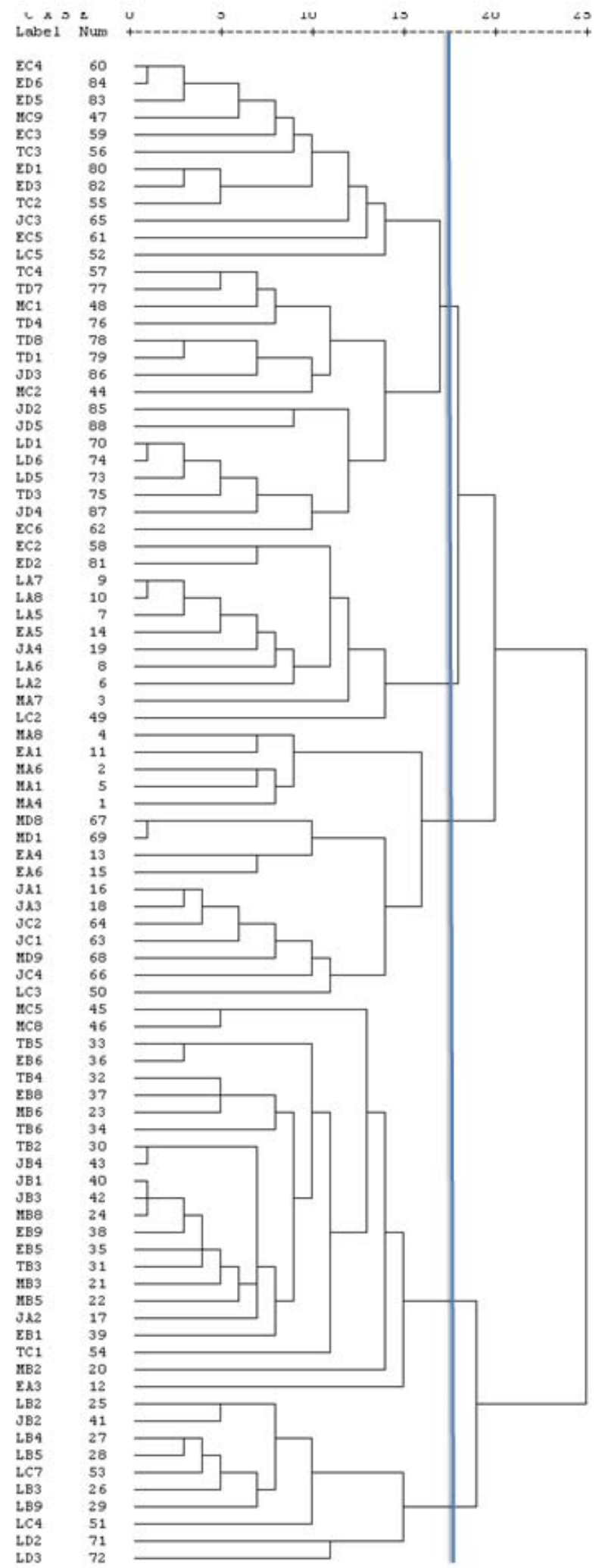

Figure 1: Dendrogram obtained from the 21 morphological characters, within group linkage method with squared Euclidean distance. Accessions are indicated with A, B, C and D for Mari, Zard, Shengeh and Rowghani cultivars respectively. Regions are indicated with L, M, E, T and J for Aliabad, Gilvan, Manjil, Tarom and Jamalabad respectively. 
Table 4: Summary of canonical discriminant functions

\begin{tabular}{ccccc}
\hline Function & Eigenvalue & \% of variance & Cumulative $\%$ & Canonical correlation \\
\hline 1 & 7.245 & 55.2 & 55.2 & 0.937 \\
2 & 3.536 & 26.9 & 82.1 & 0.883 \\
3 & 2.077 & 15.8 & 98.0 & 0.822 \\
4 & 0.266 & 2.0 & 100.0 & 0.460 \\
\hline
\end{tabular}

Table 5: Standardized canonical discriminant function coefficients of characters in olive cultivars

\begin{tabular}{ccccc}
\hline Characters & \multicolumn{3}{c}{ Function } & \multicolumn{1}{c}{. } \\
\hline Leaf length & 1 & $\underline{0.461}$ & 0.363 & -0.064 \\
Fruit mass & -0.05 & -0.152 & $\underline{0.445}$ & 0.351 \\
Presence of lenticels & -0.036 & -0.058 & $\underline{0.841}$ & 0.151 \\
Fruit apex & -0.305 & 0.321 & -0.337 & $\underline{0.827}$ \\
Stone shape & $\underline{0.670}$ & -0.655 & -0.245 & 0.337 \\
Stone base & 0.614 & $\underline{0.740}$ & -0.082 & 0.215 \\
\hline
\end{tabular}

\subsection{ISSR polymorphism}

The 11 ISSR primers produced 77 polymorphic bands by each primer ranged from 4-10. The highest number of polymorphic bands was obtained by UBC 808 (10 bands), while UBC 815 produced the lowest number of polymorphic bands (3 bands). PIC values ranged from 0.319 (UBC 810 ) to 0.46 (HB 12) (Table 2). The mean values of EMR, MI, effective number of alleles $(\mathrm{Ne})$, Nei's genetic diversity $(\mathrm{H})$ and Shannon index (I) for all the primers were $6.14,2.37,1.73,0.4$ and 0.6 respectively (Table 6). Among the primers, UBC 822 and UBC 816 showed that the highest number of effective alleles (1.92)

The AMOVA showed that most of the genetic diversity was attributable to differences among individuals within cultivars $(91 \%)$ rather than among cultivars $(9 \%)$ (Table 7$)$. The calculated PhiPT for all individuals (0.086) was significant $(P<0.01)$.

The highest amount of polymorphism, Shannon's index and heterozigosity was observed in 'Zard' cultivar and the lowest polymorphism and heterozigosity in 'Mari' (Table 8). The number of effective allele varied from 1.62 to 1.67. Percent of polymorphism varied from 92.39 to 97.83 . The highest polymorphism may be due to high efficiency of markers. Based on the results, the highest and lowest coefficient of Nei's genetic distance between cultivars were belonged to 'Mari' with 'Shengeh' (0.105) and 'Zard' with 'Rowghani' (0.061), respectively (Table 9).

Table 6: Genetic diversity parameters estimated for the ISSR primers in 88 accessions. PIC = polymorphic information content; $\mathrm{EMR}=$ effective multiplex ratio; $\mathrm{MI}=$ marker index; $\mathrm{Ne}=$ number of effective alleles; $\mathrm{H}=$ Nei's index; I = Shannon's information index.

\begin{tabular}{|c|c|c|c|c|c|c|c|}
\hline & Primer name & $\mathrm{PIC}$ & EMR & $\mathrm{MI}$ & $\mathrm{Ne}$ & $\mathrm{H}$ & $\mathrm{I}$ \\
\hline 1 & UBC 834 & 0.42 & 9 & 3.78 & 1.63 & 0.36 & 0.55 \\
\hline 2 & UBC807 & 0.37 & 7 & 2.59 & 1.63 & 0.36 & 0.53 \\
\hline 3 & UBC 808 & 0.38 & 10 & 3.8 & 1.77 & 0.43 & 0.76 \\
\hline 4 & UBC 809 & 0.4 & 5.14 & 2.06 & 1.84 & 0.45 & 0.65 \\
\hline 5 & UBC 810 & 0.31 & 3.6 & 1.11 & 1.54 & 0.32 & 0.49 \\
\hline 6 & UBC 822 & 0.37 & 8.1 & 2.99 & 1.92 & 0.48 & 0.67 \\
\hline 7 & HB 12 & 0.46 & 4.5 & 2.07 & 1.87 & 0.46 & 0.65 \\
\hline 8 & UBC 812 & 0.33 & 1.5 & 0.49 & 1.72 & 0.41 & 0.6 \\
\hline 9 & UBC 816 & 0.42 & 7 & 2.94 & 1.92 & 0.47 & 0.67 \\
\hline 10 & UBC 823 & 0.38 & 3.57 & 1.36 & 1.49 & 0.31 & 0.48 \\
\hline \multirow[t]{2}{*}{11} & UBC 825 & 0.35 & 8.1 & 2.83 & 1.67 & 0.37 & 0.55 \\
\hline & Mean & 0.38 & 6.14 & 2.37 & 1.73 & 0.4 & 0.6 \\
\hline
\end{tabular}


Table 7: Analysis of variance of olive cultivars based on molecular markers. Df $=$ degree of freedom; SS $=$ sum of squares; MS = mean squares; Est. Var = estimated variance; $\%=$ percent of diversity; PhiPT $=\mathrm{AC} /(\mathrm{WC}+\mathrm{AC})$.

\begin{tabular}{cccccc}
\hline Source & df & SS & MS & Est. Var & $\%$ \\
\hline Among Cultivar(AC) & 3 & 128.739 & 42.913 & 1.319 & 9 \\
Within Cultivar(WC) & 84 & 11.72 .465 & 13.958 & 13.958 & 91 \\
Total & 87 & 1301.205 & & 15.277 & 100 \\
\hline PhiPT $=0.086$ & & P Value $=0.001$ & \\
\hline
\end{tabular}

Table 8: Genetic diversity parameters among 4 cultivars based on ISSR loci. $\mathrm{Na}=$ number of different alleles; Ne = number of effective alleles; I = Shannon's information index; He = expected heterozygosity; SE = standard error

\begin{tabular}{ccccccc}
\hline Cultivars & Number & $\mathrm{Na} \pm \mathrm{SE}$ & $\mathrm{Ne} \pm \mathrm{SE}$ & $\mathrm{I} \pm \mathrm{SE}$ & $\mathrm{He} \pm \mathrm{SE}$ & \% polymorphism \\
\hline Mari & 19 & $1.88 \pm 0.049$ & $1.65 \pm 0.036$ & $0.533 \pm 0.023$ & $0.365 \pm 0.018$ & 92.21 \\
Zard & 24 & $1.96 \pm 0.029$ & $1.67 \pm 0.033$ & $0.554 \pm 0.020$ & $0.379 \pm 0.016$ & 97.4 \\
Shengeh & 23 & $1.95 \pm 0.025$ & $1.67 \pm 0.035$ & $0.547 \pm 0.021$ & $0.375 \pm 0.016$ & 94.81 \\
Rowghani & 22 & $1.96 \pm 0.022$ & $1.66 \pm 0.036$ & $0.544 \pm 0.021$ & $0.371 \pm 0.016$ & 96.1 \\
\hline Mean & & $1.93 \pm 0.017$ & $1.66 \pm 0.018$ & $0.544 \pm 0.011$ & $0.373 \pm 0.008$ & 95.13 \\
\hline
\end{tabular}

Table 9: Nei's genetic distance between pairs of 4 olive cultivars

\begin{tabular}{lllll}
\hline Cultivar & Mari & Zard & Shengeh & Rowghani \\
\hline Mari & 0 & & & \\
Zard & 0.082 & 0 & 0 & \\
Shengeh & 0.105 & 0.083 & 0.081 & 0 \\
Rowghani & 0.073 & 0.061 & & \\
\hline
\end{tabular}

\subsection{Genetic diversity based on ISSR data}

In the complete linkage dendrogram based on ISSR data, the 88 olive trees were separated in five clusters (Figure 2 and Table 10). The first cluster included all of the individuals of Manjil's 'Mari' and 'Zard' cultivars, four individuals of the Gilvan's 'Mari' and three individuals of the Aliabad's 'Mari'. The second cluster were placed all of the Aliabad's individuals of 'Shengeh' and 'Rowghani' cultivars and four individuals of the Gilvan's 'Shengeh'. Cluster 3 grouped all of the individuals of Jamalabad's 'Rowghani' and four individuals of the Aliabad's 'Zard'. All of the individuals of Tarom and Manjil's 'Shengeh' grouped in cluster 4 . Claster 5 was formed by diverse individuals. Cultivars and origins couldn't form distinct cluster. Aliabad and then Manjil were able to place their individuals of each cultivar in similar cluster, in other words, these areas showed the most homogeneity. The Mantel analysis revealed a negative and significant correlation ( $\mathrm{r}=-0.164 p<0.001,1000$ random permutations) between the morphological and ISSR markerderived dissimilarity matrices.

Table 10: Grouping the accessions in 5 clusters. Accessions are indicated with A, B, C and D for Mari, Zard, Shengeh and Rowghani cultivars respectively. Regions are indicated with L, M, E, T and J for Aliabad, Gilvan, Manjil, Tarom and Jamalabad respectively.

\begin{tabular}{|c|c|c|}
\hline Cluster & number & olive accessions \\
\hline 1 & 18 & $\begin{array}{l}\text { MA4, MA6, MA7, MA8, LA2, LA5, LA6, EA1, EA3, EA4, EA5, EA6, EB5, EB6, } \\
\text { EB8, EB9, EB10, MC10 }\end{array}$ \\
\hline 2 & 22 & $\begin{array}{l}\text { LA7, LA8, MB6, MB8, TB3, TB5, TB6, MC2, MC5, MC8, MC9, LC2, LC3, LC4, } \\
\text { LC5, LC7, LD1, LD2, LD3, LD5, LD6, TD3 }\end{array}$ \\
\hline 3 & 16 & JA1, JA3, LB2, LB4, LB5, LB9, TB4, JB4, JC2, JC4, JC5, ED6, JD2, JD3, JD4, JD5 \\
\hline 4 & 21 & $\begin{array}{l}\text { JA2, JA4, JB1, JB2, JB3, TC1, TC2, TC3, TC4, EC2, EC3, EC4, EC5, EC6, JC3, TD8, } \\
\text { TD10, ED1, ED2, ED3, ED5 }\end{array}$ \\
\hline 5 & 9 & MA10, MB2, MB3, MB5, LB3, TB2, MD8, MD9, MD10 \\
\hline
\end{tabular}




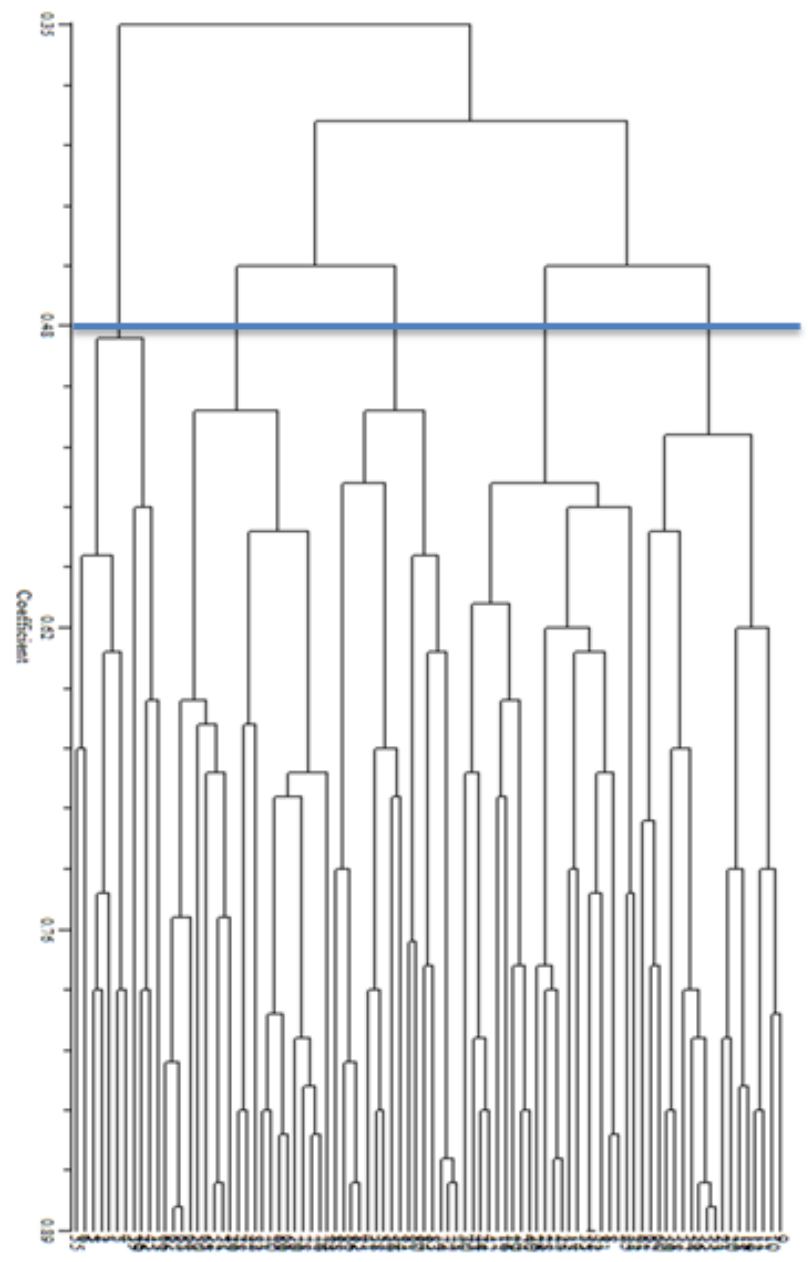

Figure 2: Complete linkage dendrogram based on simple matching coefficient illustrating the genetic similarities and distance among 88 olive accessions obtained by 11 ISSR primers data

\section{DISCUSSION}

Homogeneity in Aliabad trees was bigger than those of other regions. This orchard, in contrast to others, is vegetative collection. Among other cultivars, 'Zard' and 'Mary' had more homogeneity according morphological characters. Weakness of these classifications have been shown by the evidence that chemical and morphological changes in olive trees as well as other plants are influenced by domestication and agronomic selection (Sheidai et al., 2007). The high homogeneity in cultivars may reflect the selection pressure for fruit quality (Mekuria et al., 2002). Each of them was grouped in two clusters. Aliabad individuals were separated in cultivars. Cluster 2 of 'Mari' trees had acute fruit apex, rugose stone surface and few lenticels. Whereas, 'Mari' individuals in cluster 3 had obtuse fruit apex, smooth stone surface and many lenticels. 'Zard' individuals in cluster 4 had very high fruit mass, very high stone mass, spherical stone shape and many lenticels. While, 'Zard' individuals in cluster 5 had high fruit mass, high stone mass, ovoid stone shape and few lenticels.

The result showed high allelic variation in 11 ISSR markers, from which four ISSR primers had the highest amount (100\%). These four primers could be used to study genetic variation among olive genotypes. The highest level of polymorphism at ISSR loci indicates high genetic variability in olive cultivars which is in agreement with other studies (Gemas et al., 2004; Essadki et al., 2006; Terzopoulos et al., 2005; Martins-Lopez et al., 2009; Hess et al., 2000). Good discrimination 
efficiency and high reproducibility of ISSRs make them particularly suitable to identify the closely related clones which are often the results of very local selection in fruit species (Essadki et al., 2006). The UBC 822 gave the highest number of effective alleles (1.92) and Nei's genetic diversity (0.48) among the ISSR primers, while the UBC 823 primer gave the lowest values for number of effective alleles (1.49), Nei's genetic diversity $(0.31)$ and Shannon index (0.48).

The 'Mari' showed the highest homogeneity based on both data analyses and often their individuals were placed close to each other, while the highest genetic diversity compared to other cultivars was observed for the 'Shengeh'. Intra-cultivar variation has also been reported in 'Shengeh' by using morphological characters (Hosseini-Mazinani et al., 2004). 'Mari' cultivar showed the lowest mean of Shannon's index (0.533) and high genetic distance with the other cultivars, indicating little or low gene flow with other cultivars take place. 'Zard' and 'Rowghani' showed the lowest Nei's genetic distance. In the other study 'Zard', 'Rowghani' and 'Dezfool' were placed together and they showed low genetic distance, therefore, they reported probably those cultivar had the same origin (Koohi-dehkordi et al., 2006). A good correlation was not found between genetic distances estimated using ISSR markers and those based on morphological characteristics. This may be a consequence of the fact that molecular analysis probes a wider area of the genome than does morphological analysis (Rao et al., 2009). The lack of correlation between those two estimates is also influenced by the fact that a large proportion of the variation detected in trees by ISSR is, a priori, non-adaptive (Karhu et al., 1996), and hence not subject to selection, unlike phenotypic attributes (Rao et al., 2009).

Noormohammadi observed high intra-cultivar variation among North Iranian olive cultivars and without geographical separation (Noormohammadi et al., 2007; Noormohammadi et al., 2009; Noormohammadi et al., 2014), which was in agreement with the present study. Lack of a clear clustering of olive may be due to material exchanges by local gardeners and complicated in their denominations because of morphological similarity (Noormohammad et al., 2009). 'Mari' has narrow and elongated form of fruit, unlike other cultivars and identifying them is easier than others. The high intra-cultivar variation was obtained from most woody perennial outbreeding species, with most variation being within populations and existence of low gene flow (Hamrich and Godt, 1989).

\section{MAIN CONCLUSION}

In this paper, four olive cultivars have been investigated and characterized by combining morphological and molecular data. An important issue in identification of cultivars by morphological characters is the use of features receiving the least effects from environmental factors. Based on our analyses, characters of fruit and stone were more important than leaf characters. Both morphological and ISSR data analyses showed intra- and inter cultivar genetic diversity. These local cultivars must be exploited to identify individuals highly adaptive to extreme environmental conditions.

\section{REFERENCES}

Angiolillo, A., Mencuccini, M., \& Baldoni, L. (1999). Olive (Olea europaea L.) genetic diversity assessed Amplified Fragment Length Polymorphisms. Theoretical and Applied Genetics, 98: 411-421. Doi: 10.1007/s001220051087

Bandelj, D., Jakše, J., \& Javornik, B. (2002). Characterisation of olive (Olea europaea L.) cultivars by RAPD marker. Acta Horticulturae,
586: 133-135.

Doi:

10.17660/ActaHortic. 2002.586.20

Belaj, A., Trujillo, I., De La Rosa, R., Rallo, L., \& Gimenez, M. J. (2001). Polymorphism and discrimination capacity of randomly amplified polymorphic markers in olive germplasm bank. American Society for Horticultural Science, 126: 64-71. 
Belaj, A., Rallo, L., Trujillo, I., \& Baldoni, L. (2004). Using RAPD and AFLP markers to distinguish individuals obtained by clonal selection of Arbequina and Manzanilla de Sevilla olive. Horticultural Science, 39: 1566-70.

Besnard, G., Berton, C., Baradat, P., Khadari, B., \& Berville, A. (2001). Cultivar identification in olive (Olea europaea L.) based on RAPDs. American Society for Horticultural Science, 126: 668-675.

Cipriani, G., Marrazo, M. T., Marconi, R., Cimato, A., \& Testolini, R. (2002). Microsatellite markers isolated in olive (Olea europaea L.) are suitable for individual fingerprinting and reveal polymorpgism within ancient cultivars. Theoretical and Applied Genetics, 104: 223-228. Doi: $10.1007 / \mathrm{s} 001220100685$

Dastkar, E., Soleimani, A., Jafary, H., \& Naghavi, M. R. (2013). Genetic and morphological variation in Iranian olive (Olea europaea L.) germplasm. Crop Breeding Journal, 3(2): 99-106.

Diaz, A., De La Rosa, R., Martin, A., \& Rallo, P. (2006). Development, characterization and inheritance of new microsatellites in olive (Olea europaea L.) and evaluation of their usefulness in cultivar identification and genetic relationship studies. Tree Genetics \& Genomes, 2: 165- 175. Doi: $10.1007 / \mathrm{s} 11295-006-0041-5$

Doyle, J. J., \& Doyle, J. L. (1990). Isolation of plant DNA from fresh tissue . Focus, 12: 13-15.

Essadki, M., Ouazzani, N., Lumaret, R., \& Moumni, M. (2006). ISSR variation in olive-tree cultivars from Morocco and other western countries of Mediterranean Basin. Genetic Resources and Crop Evolution, 53: 475-482. Doi: 10.1007/s10722-0041931-8

Gemas, V. J. V., Almadanim, M. C., Tenreriro, R., Martins, A., \& Fevereiro, P. (2004). Genetic diversity in the olive tree (Olea europaea L. subsp. europaea) cultivated in Portugal revealed by RAPD and ISSR markers. Genetic Resources and Crop Evolution, 51: 501-511. Doi: 10.1023/B:GRES.0000024152.16021.40

Hamrick, J. L., \& Godt, M. J. W. (1989). Allozyme diversity in plant species. In: Brown, A.H.D., Clegg, M.T., Kahler, A.L., Weir, B.S. (Eds.), Plant Population Genetics, Breeding and Genetic Resources. Sinauer Associated Sunderland, MA, pp. 43-63.

Hegazi, E. S., Hegazi, A. A., Tawfic, A. A., \& Sayed, H. A. (2012). Molecular characterization of local and important olive cultivars grown in Egypt using ISSR technique. Journal of Horticultural Science \& Ornamental Plants, 4(2): 148-154.
Hess, J., Kadereit, J.W., \& Vargas, P. (2000). The colonization history of Olea europaea L. in Macaronesia based on internal transcribed spacer 1 (ITS-1) sequences, randomly amplified polymorphic DNAs (RAPD), and intersimple sequence repeats (ISSR). Molecular Ecology, 9: 857-867. Doi: 10.1046/j.1365-294x.2000.00942.x

Hosseini- Mazinani, S. M., \& Samaee, M. (2004). Multivariate analyses of intra-cultivar variation of a local olive cultivar in the Northern part of Iran using morphological traits. Acta Horticulture, 791: $65-71$.

International Olive Council (IOC). (1982). Unified Qualitative Standard Applying to table olives in international trade. Madrid.

Karhu, A., Hurme, P., Karjalainen, M., Karvonen, P., Karkkainen, K., Neale, D., \& Savolainen, O. (1996). Do molecular markers reflect patterns of differentiation in adaptive traits of conifers? Theoretical and genetics, 93: 215-221.

Khadari, B., Breton, C., Moutier, N., Roger, P. J., Besnard, G., Berville, A., \& Dosba, F. (2003). The use of molecular markers for germplasm management in a French olive collection. Theoretical and Applied Genetics, 106: 521-529.

Koohi-dehkordi, M., Rahimmalek, M., Sayedtabatabaei., B. E., Baninasab, B., \& Mobli, M. (2006). Assessment of genetic relationships among some of the Iranian and forign olive cultivars using ISSR markers. Iranian Journal of Horticultural Science and Technology. 7(2): 93-10.

Mekuria, G. T., Collin, G. C., \& Sedgley, M. (1999). Genatic variability between different accessions of some common commericial olive cultivars. The journal of Horticultural and Science Biotechnology, $74 \quad$ (3): 309-314. Doi: 10.1080/14620316.1999.11511114

Mecuria, GT., Collins, G., \& Sedgley, M. (2002). Genetic diversity within $\mathrm{n}$ isolated olive (Olea europaea L.) population in relation to feral spread. Scientia Horticulturae, 94: 91-105. Doi: 10.1016/S0304-4238(01)00375-2

Milotić, A., Setić, E., Persurić, D., Puljuha, D., Sladonja, B. and Brščić, K. 2005. Identification and characterization of autochthonous olive varieties in Istria (Croatia). Annales Ser hist nat. 15 (2): 251256.

Noormohammadi, Z., Hosseini-Mazinani, M., Belaj, A., Trujillo, I., Rallo, L., \& Sadeghizade, M. (2007). Identification and classification of main Iranian olive cultivars using microsatellite markers. Hortscince, 42(7): 1545-1550.

Acta agriculturae Slovenica, 106 - 2, september 2016 
Noormohammadi, Z., Sheidai, M., Dehghani, A., Parvini, F., \& Hosseini-Mazinani, S. M. (2012). Inter-population genetic diversity in Olea cuspidata subsp. Cuspidata revealed by SSR and ISSR markers. Acta Biologica Szegediensis, 56(2): 155163.

Omrani-Sabbaghi, A., Shahriari, M., Falahati-Anbaran, M., Mohammaddi, S. A., Nankali, A., Mardi, M., \& Ghreyazie, B. (2007). Microsatellite markers based assessment of genetic diversity in Iranian olive (Olea europaea L.) collections. Scientia Horticulturae, 112 (4): 439-447. Doi: 10.1016/j.scienta.2006.12.051

Owen, C. A., Bita, E. C., Banilas, G., Hajjar, S. E., Sellianakis, I., Hatzopoulos, P., \& Kalaitzis, P. (2005). AFLP reveals structural details of genetic diversity within cultivated olive germplasm from the Eastern Mediterranean.Theoritical and Applied Genetics, 110: 1169-1176. Doi: 10.1007/s00122004-1861-z

Pasqualone, A., Caponio, F. \& Blance, A. (2001). Intersimple sequence repeat DNA markers for identification of drupes from different Olea europaea L. cultivars. European Food Research and Technology, 213: 240-243. Doi: $10.1007 / \mathrm{s} 002170100367$

Peakall, R., \& Smouse, P E. (2006). GENEALEX 6: genetic analysis in Excel. Population genetic software for teaching and research. Molecular Ecology Resources. Notes 5: 288-295.

Rao, R., La Mura, M., Corrado, G., Ambrosino, O., Foroni, I., Perri, E., \& Pugliano, G. (2009). Molecular diversity and genetic relationships of southern Italian olive cultivars as depicted by AFLP and morphological traits. Journal of Horticultural Science \& Biotechnology, 84(3): 261-266. Doi: 10.1080/14620316.2009.11512514

Rallo, P., Dorado, G., \& Martin, A. (2000). Development of simple sequence repeats (SSR) in olive tree (Olea europaea L.). Theoretical and Applied Genetics, 101:984-989. Doi: $10.1007 / \mathrm{s} 001220051571$

Rohlf, F J. (1998). NTSYS-pc. Numerical taxonomy and multivariate analysis system. Version 2.00. Exeter Software, Setauket, N. Y.

Rotondi, A., \& Magli, M. (1999).Valutazione comparative dellasensibilita a minimetermichecritiche di cultivar di olive della Romagna. Olive \& Oil,1: 48-54.

Sadeghi, H. (1992). Cultivation, preservation and harvesting of olive. Publication of the Agricultural Ministry, Tehran, Iran.

Samaee, S. M., Shobbar, Z. S., Afshari, H., HosseiniMazinani, M., \& Aheidai, M. (2003). Molecular characterization of olive germplasm in Iran by use of Random Amplified Polymorphic DNA (RAPD): Correlation with phenotypic studies. Acta Horticulture, 623: 169-175. Doi: 10.17660/ActaHortic.2003.623.18

Sanz-Cortes, F., Parfit, D. E., Romero, C., Struss, D., Liacer, G., \& Badenes, M I.( 2003). Intraspecific olive diversity assessed with AFLP. Molecular Breeding, 122: 173-177. Doi: 10.1046/j.14390523.2003.00808.x

Sefc K. M., Lefort, F., Grando, M. S., Scott, K. D., Steinkellner, H. \& Thomas, M. R. (2001). "Microsatellite markers for grapevine: A state of the art". in Roubelakis. K. A. Molecular biology and biotechnology of grapevine. Kluwer Academic Publisher. 433-444. Doi: 10.1007/978-94-0172308-4_17

Sensi, E., Vignani, R., Scali, M., Masi, E., \& Cresti, M. (2003). DNA fingerprinting and genetic relatedness among cultivated varieties of Olea europaea L. estimated by AFLP analysis. Scientia Horticulturae, 97: 378-388. Doi: 10.1016/S0304-4238(02)00163-2

Sheidai, M., H-Shahriari, Z., Noormohammadi, Z., Parisan, H., \& Farahani, F. (2007). Study of genetic diversity in some olive (Olea europaea L.) cultivars by using RAPD markers. Pakistan Journal of Boilogical Science, 10 (17): 2972-2975. Doi: 10.3923/pjbs.2007.2972.2975

Terzopoulos, P.J., Kolano, B., Bebeli, P.J., Kaltsikes, P. J., \& Metzidakis, I. (2005). Identification of Olea europaea L. cultivars using inter-simple sequence repeat markers. Scientia Horticulturae, 105: 45-51. Doi: 10.1016/j.scienta.2005.01.011

Wiesman, Z., Avidan, N., Lavee, S., \& Quebedeaux, B. (1998). Molecular characterization of common olive varieties in Israel AND THE West Bank using randomly amplified polymorphic DNA (RAPD) markers. American Society for Horticultural Science, 123: 837-841. 